\title{
Ajattelun DYNAAMISUUDESTA
}

Voiko ajattelu tavoittaa oman perustansa? Silmä ei näe itseään. Kykeneekö ajattelu ajattelemaan itseään? En usko, joskin ajattelu voi varmasti selventää, mitä tarkoittaa ajatella; aivan kuten silmä voi selventää, mitä tarkoittaa nähdä. Mutta en toisaalta myöskään usko, että ajattelun tarkoitus olisi ajatella itseään. Silmänkään tarkoitus ei ole katsella itseään. Älkäämme pitäkö asioiden ja ilmiöiden puutteina sellaisia seikkoja, jotka eivät vastaa niiden maailmallista asemaa.

Ajattelun olennainen ongelma on pitää itsensä koossa; voisi sanoa: on kyettävä pysäyttämään liike siten, että liiketila säilyy. Tämän saavuttamiseksi tarvitaan harjaannusta ja ohjenuoria. Hyödyllisiä ohjenuoria on esitetty kautta aikojen, mutta niiden harmilliseksi kohtaloksi on usein koitunut muuttua ajattelua kahlitseviksi normeiksi. Oman kulttuurimme perinteisiä normeja ovat esimerkiksi rationaalisuus ja kalkyyli. Molemmilla on ajattelussa välttämätön sijansa, mutta ajattelu ei pelkisty rationaalisuuteen ja kalkyyliin.

Jos ajattelun muotoutumista ei voi palauttaa sen omiin sääntöihin niin mihin sitten? Yksinkertaistaen: ajattelun historiallisen liikevoiman ovat muodostaneet ihmisten aineellisen ja yhteisöllisen toimeentulon sekä yhteiskunnallisen järjestyksen ja vallan samanaikaiset muodonmuutokset. Yhteiskunnan ja ajattelun historialliset murrokset ovat osuneet yksiin. Murrokset ovat muuttaneet ihmisten kykyä ajatella erityisesti mullistamalla ajattelevien subjektien suhteen sekä toisiinsa että maailmaan. Cornelius Castoriadis piti kriittistä kapasiteettia inhimillisen ajattelun kallisarvoisimpana ominaisuutena ja esitti, että kriittisen ajattelun synnyinsijoja ovat olleet kreikkalainen polis sekä Euroopan myöhäiskeskiajan kaupungit. ${ }^{1}$

Ajattelun dynaaminen liike on historiallisesti muotoutunutta. Historiaa ei voi sitä tarkasteltaessa välttää. Ajattelun dynamiikka on kuitenkin myös käytännöllinen kysymys, jolla on merkitystä tutkimuksellisten taitojen kehittymiselle. Esitän seuraavassa joukon ajattelun liikettä hahmottavia pohdintoja. 
Ajattelu on työtä. Se on aineellinen tosiasia. Ajattelun perustana ovat keskushermostossa tapahtuvat sähkökemialliset värähtelyt, joiden ylläpitäminen vaatii energiaa. Elinvoimainen organismi pitää keskushermostonsa toiminnassa huomaamattaan. Olennaista kuitenkin on, että aivojen toimintakyvyn turvaaminen vaatii huomattavasti suuremman määrän energiaa aivokudoksen painoyksikköä kohden kuin ihmiskehon muiden kudosten ylläpitäminen keskimäärin. Nykyisten yhteiskuntien hyvinvoiville kansalaisille tällä ei ole käytännöllistä merkitystä, sillä heidän ravinnon (energian) tarpeensa tulee ylenpalttisesti tyydytetyksi. Asetelman taustalla on kuitenkin vakava tosiasia: kriittisten ravinteiden puute vauva- tai kasvuiässä vahingoittaa aivojen kehitystä. Ajattelukyvyn historialliselle kehitykselle tämä seikka on ollut merkityksellinen. Inhimillisten yhteisöjen vakiintumisen varhainen ehto on ollut, että niiden jäsenet ovat saaneet riittävän korkealaatuista ravintoa. On hyvin uskottavaa, että ruoan, erityisesti lihan kypsentäminen on ollut olennainen kulttuurin varhaishistorian edistysaskel. ${ }^{2}$

Ajattelu on työtä myös sikäli, että sen onnistuminen vaatii aineksia, välineitä ja taitoja. Ajateltaessa on koetettava luoda ja muokata johdonmukaisia ajatuskulkuja ja päättelyketjuja ulottuvilla olevia aineksia käyttäen. Ajattelun ainekset ja taidot ovat kielellisiä, mutta ajattelun kielellisen artikulaation taustalla on käytännöllinen ja kehollinen kokemus. Ajattelun aineksilla on ei-kielellinen perusta. Ajattelu on siis vanhempaa kuin käsitteellisesti artikuloitunut kieli. Symbolit ja rituaalit kantavat tätä perintöä kulttuurien toimintojen käytännöissä. Kuten Marcel Mauss totesi, rituaalien perustana on ihmisten aineelliseen toimeentuloon liittyvä eräänlainen "tekemisen magiikka": Mikä selittää sen, että kykenen elämään maailmassa ja muuttamaan maailmaa? Johtuuko se, että saan saaliin, minusta vai maailmasta? Mikä saa minun suhteeni maailmaan jäsentymään sellaiseksi, että viljelmäni tuottaa satoa? ${ }^{3}$

Kulttuurin muotoutuminen ihmisten jokapäiväisten vuorovaikutusten tuloksena käsittää edelleen vastaavanlaisen maagisen ulottuvuuden, josta Pierre Bourdieu käytti nimitystä "sosiaalinen alkemia". Ihmisten keskinäiset vuorovaikutukset tuottavat kulttuurisia ilmiöitä, jotka ovat yksityisten ihmisten vaikutusvallan ulottumattomissa. Uusien merkitysten luomiseen osallistuu suuri määrä ihmisyksilöitä ja -ryhmiä vaihtelevin tavoin. Siksi on hyvin uskottavaa, että väkiluvun kasvu ja sen tuottama uudenlaisten kaupunkimaisten yhteisöjen muodostuminen on olennaisesti muuttanut inhimillisen ajattelun historiallisia edellytyksiä.

Ajattelu ei pelkisty "tietoisuudeksi", mikäli tämä ymmärretään puhtaasti intellektuaaliseksi käsitteeksi. Termi 'kognitio' on osuvampi. Se viittaa aktiiviseen toimintaan, joka on alaltaan laajempaa kuin tietoinen ajattelu. Elävä organismi voi kognition avulla päästä perille maailmasta ja omasta asemastaan siinä. Peter Gärdenfors on esittänyt kognitiosta kolmitasoisen mallin käyttäen tasojen erotteluperustana sitä, millaisista aineksista kognition tuloksena syntyvä ympäröivän maailman representaatio koostuu. Gärdenfors kuvaa representaation tasoja termeillä 'esikäsitteellinen', 'käsitteellinen' ja 'symbolinen'. Vastaavat kognitiivisen toiminnan tasot jäsentyvät suunnilleen seuraavasti: esikäsitteellinen kognitio tunnistaa ilmiöiden samankaltaisuuksia ja erilaisuuksia; käsitteellinen kognitio jakaa ilmiöitä samankaltaisuuksien perusteella luokkiin, joita kielen omaksuneet oliot eli ihmiset kuvaavat erilaisilla yleisnimillä; symbolinen kognitio arvioi ilmiöiden merkityksiä ja vertaa niitä toisiinsa symbolisten merkityssuhteiden jäsentämässä semanttisessa tilassa. ${ }^{4}$

Gärdenforsin skeema on innostava ainakin kahdessa mielessä. Yhtäältä se kattaa 
kaikkien ympäristöään aktiivisesti havainnoivien ja siihen reagoivien organismien kognitiiviset toiminnot ja tarjoaa siis periaatteessa mahdollisuuden verrata ihmisten ja muiden eläinten kognitiivisia toimintoja ja kykyjä toisiinsa. Toisaalta se osoittaa inhimillisen erityisyyden: ihmiset kykenevät symbolien avulla luomaan maailman, joka voi olla ja usein onkin havaitusta maailmasta täysin irrallinen. Symboliset maailmat ovat inhimillisiä konstruktioita, mutta ne ovat tosia nimenomaan siksi, että ne ovat konstruktioita. Matematiikka, logiikka ja uskonnolliset oppirakennelmat ovat tässä suhteessa keskenään samankaltaisia. Materiaalisilla konstruktioilla, kuten asumuksilla, kaupungeilla, temppeleillä ja katedraaleilla, on niiden kanssa paljon yhtymäkohtia. Mutta erilaiset konstruktiot tarjoavat inhimillisille kognitiivisille käytännöille sekä ajattelulle aivan erilaisia lähtökohtia.

Dualistiset jäsennykset ovat varhaisimpien nykyaikaan asti välittyneiden maailman representaatioiden hallitseva piirre. Dualismeja on sekä uskonnollisten oppien että klassisen Kreikan filosofisen ajattelun taustalla. ${ }^{5}$ Inhimillisen ajattelun historiallinen saavutus on ollut luoda yksinkertaisten dualismien tilalle moniulotteisia, inhimillisyyden ehtoja kuvaavia käsitteellis-symbolisia jäsennyksiä.

\section{2 .}

Työnteko luo vastavuoroisen dynamiikan tekijän ja tekemisen kohteen välille: työ suuntautuu kohteeseen, jota se muuttaa, ja kohteen muuttuminen muuttaa puolestaan työn tekemistä.

Ajattelun dynamiikka on samalla tavoin vastavuoroista. Dynamiikan voi tässä ymmärtää joko Aristoteleelta periytyvässä merkityksessä ilmiöiden yleisenä liikkumisen ja aktiivisuuden potentiaalina tai klassisen mekaniikan vakiinnuttamassa merkityksessä, jonka 1800-luvun suuri fyysikko James Clerk Maxwell tiivisti ilmaukseen "muutos voiman vaikutuksesta". Edellisestä voi johtaa tulkinnan, että ajattelulla on sisäsyntyinen potentiaali tai liikevoima. Ajattelija kokee oman ajattelunsa ikään kuin luonnonvoimaisena välttämättömyytenä. Klassisen mekaniikan dynamiikkaajatuksen mukainen tulkinta puolestaan korostaa sitä, että ajatuskulut muuttuvat ja häiriintyvät sekä sisäisistä että ulkoisista syistä. "Voima", joka vaikuttaa ajatteluun, voi olla mikä tahansa muutos ajattelijan ulkoisessa (äänet ja hälyt) tai sisäisessä (hammassärky) ympäristössä. Ajattelussa on osallisena ihmisen koko keho, jonka on turvattava ajattelulle suosiollinen tausta.

Ajattelun fysiologisen perustan muodostavat hermostossa lukuisilla eri taajuuksilla tapahtuvat sähkövärähtelyt. Nopeimpien kesto on sekunnin tuhannesosia, pisimpien joitakin kymmeniä sekunteja. Kognition koherenssi edellyttää, että eri taajuuksilla tapahtuvat värähtelyt synkronoituvat yhtenäisiksi rytmeiksi. Tämän turvaaminen tuottaa organismeille erittäin merkittävän samanaikaisuuden ongelman, jonka anatomis-fysiologisista ratkaisuista seuraa hermostolle ja lihaksistolle toiminnallisia rajoitteita. Lihasmotoriikan suurin mahdollinen taajuus on hiukan toistakymmentä hertsiä (eli värähdystä sekunnissa); sitä nopeammiksi ei pianisti voi sormiensa liikkeitä saada harjoittelipa hän kuinka paljon tahansa. Käsitteellisen ja symbolisen ajattelun pitäminen koherentisti koossa asettaa luultavasti hermostolle vastaavanlaisia ongelmia, joiden ydin lienee siinä, että erityyppiset kognitiiviset toiminnot edellyttävät erisuuruisten keskushermoston kimppujen synkronoitumista keskenään sopusointuisiin rytmeihin. ${ }^{6}$

Ajattelu on alttiimpaa sekä ulko- että sisäsyntyisille häiriöille kuin aineellinen, lihasvoimaan perustuva työnteko. Tällä on ilmeinen perusta siinä, että fyysinen työ 
on kytketty materiaaleille ja työkaluille ominaisiin viiveaikoihin, jotka vakauttavat työsuorituksia. Yksi ammattitaidon olennaisista ilmentymistä on tekijän kyky luoda omille liikkeilleen ja työvälineidensä liikkeelle yhteinen rytmi. Tämä helpottuu, mikäli työnteon ainekset ovat helposti saatavilla. Verstaan tai työmaan järjestys on olennainen osa työnteon rytmiä. Toimintojen vakautuminen ja oikeat rytmit tuottavat tulokseksi sen, että käytännölliset toiminnot, kuten puutarhamaan muokkaaminen, puusepäntyö, kutominen tai ruoan laitto, tapahtuvat kuin itsestään.

Myös ajattelutyön onnistuminen edellyttää välineiden hallintaa ja ainesten saatavillaoloa. Tieteen ja etenkin filosofian historia on tavattu kuvata pelkästään tietoisen ymmärryksen historiana, mutta kokemus kertoo muuta. Lainaan seuraavassa ajattelun ja käytännöllisen tekemisen keskinäisestä yhteydestä pari varhaista toteamusta, jotka ovat erityisen virkistäviä siksi, että yhteydet tulevat alkuteksteissä esitetyiksi kuin ohimennen. Joseph Schumpeter käytti talousajattelun historiaa koskevassa suurteoksessaan termiä "välineistetty tieto" (tooled knowledge) arvioidessaan katolisesta kirkosta irtaantuneiden, käytännöllistä tietämystä kehittäneiden intellektuellien merkitystä Euroopan renessanssille. Esimerkkeinä välineisiin kiinnittyneen tietämyksen kohdealoista Schumpeter mainitsi anatomian, perspektiivin ja mekaniikan. Matemaatikko George Pólya tiivisti Galileo Galilein kokeellisen tutkimusmenetelmän nerokkaan ytimen lausahdukseen "kaikki fyysikot käyttävät pääään; parhaat ajattelevat myös sormillaan"?

Menestyksellisen työnteon olennainen piirre on dynaaminen vakaus, olipa kyse ajattelusta tai fyysisestä työstä. Dynaamisen vakauden ylläpitäminen tuottaa ongelmia, joille tarjoaa analogian polkupyöräily pehmeällä ja epätasaisella soratiellä. Tekeminen ei saa pysähtyä paikalleen, mutta se ei myöskään saa hajota hallitsemattomaksi horjahteluksi.

\section{3.}

Ajattelu on kollektiivista kuten kaikki työnteko. Aineellisen työn kollektiivisuuden tuo ilmi työkalujen ja taitojen yhteisöllinen historia. Ilman kykyä lujittaa työn yhteisöllisyyttä ihmiset eivät olisi kyenneet luomaan nykyisenkaltaisia kulttuureita. Inhimillisen kulttuurihistorian syvä ajallinen kerrostuma muodostuu taidoista valmistaa ja käyttää työkaluja.

Ajattelun yhteisöllisyys perustuu erityisesti kielen kollektiiviseen luonteeseen. Merkityksellinen kieli voi olla vain yhteisesti luotua ja ymmärrettyä, mutta sen lisäksi elinvoimainen ajattelu vaatii tuekseen ihmisten moninaisista keskinäisistä vuorovaikutuksista kasvavaa energiaa. "Kognitio ja sosiaalisuus ovat yhtä", totesi antropologi Alfred Gell. Kreikkalaisen ajattelun varhaisvaiheita selvittänyt Marcel Detienne ilmaisi saman seuraavasti: "Viimeistään Parmenidesta lähtien kreikkalaiset filosofit oivalsivat, että ajattelemisen välttämätön edellytys on väitellä ja argumentoida".

Argumenttien kollektiiviseen luonteeseen viittaa myös Wittgensteinin aforismi: "Kaikki koettelu, kaikki oletuksien oikeaksi ja vääräksi osoittaminen tapahtuu jo jonkin järjestelmän puitteissa. Tämä järjestelmä ei ole mikään enemmän tai vähemmän mielivaltainen ja epäilyttävä lähtökohta kaikille argumenteillemme, vaan se kuuluu osana sen oletukseen, mitä sanomme argumentiksi. Järjestelmä ei ole niinkään lähtökohta kuin argumenttien elinympäristö." ${ }^{\prime \prime}$

Platonin Menon-dialogissaan esittämä aforismi, jonka mukaan oppiminen on mieleen palauttamista, on kirjaimellisesti todenmukainen siinä merkityksessä, että yhteisönsä jäseneksi kasvavalle, oppivalle lapselle "palautuvat mieleen" ne ajattelun 
periaatteet, jotka ovat aiemmin osoittautuneet päteviksi ja elinvoimaisiksi yhteisön piirissä.

\section{4.}

Ajattelu on aineellistunut sekä pään sisä- että ulkopuolella. Antropologi André Leroi-Gourhan korosti, että ihmistymisen historian erityispiirre muihin eläinlajeihin verrattuna on ihmisorganismin ja hänen ympäristönsä keskinäiseen suhteeseen liittyvien biologisten toimintojen ulkoistuminen. Sitä ovat ilmentäneet työkalujen käyttö ja teknologisten systeemien kehitys mutta myös muistin kiinnittyminen ihmiskehon ulkopuolella oleviin artefakteihin ja merkkeihin. Leroi-Gourhan käytti termiä 'grafismi' kuvaamaan inhimillistä kykyä "ilmaista ajatuksia materiaalisten symbolien avulla". Ihmisen kognitiivisten kykyjen evoluutiossa, jonka monia piirteitä on havaittavissa myös muiden kädellisten anatomiassa ja käyttäytymisessä, grafismia edelsivät käsien (eturaajojen) ja katseen parantunut koordinaatio sekä työkalujen käytön ja kielen yhteys. Kirjoitustaito sekä sitä edeltäneet varhaiset kuvallisen esittämisen muodot ovat tehneet mahdolliseksi sen, että inhimillinen grafismi poikkeaa täydellisesti muiden eläinlajien ilmaisukyvyistä. ${ }^{10}$

Leroi-Gourhanilta on peräisin muiden muassa arkeologi Clive Gamblen käyttämä tekninen termi chaine operátoire, jota on usein käytetty kuvaamaan monista erillisistä työvaiheista muodostuneita "ketjuuntuneita toimintamalleja". Ketjuuntuneet toimintamallit ovat ilmenneet esimerkiksi kivikautisten työkalujen valmistuksessa. Kivityökalujen valmistumiseen johtaneissa ketjuuntuneissa toiminnoissa "ajattelemisen ja tekemisen välillä ei ollut mitään rajalinjaa”. ${ }^{11}$

Se, että säännöllisinä toistetut inhimilliset toimet ovat voineet tuottaa tuloksekseen säännönmukaisina toistuvia piirteitä ihmisorganismin ja ympäröivän maailman vuorovaikutuksiin, on luonut perusteita käsityksille, että materiaalinen maailma on lainmukainen ja että siihen on mahdollista vaikuttaa. Tämä on puolestaan auttanut vakauttamaan varhaisten yhteisöjen sosiaalisia suhteita ja yhteisöjen jäsenten keskinäistä kommunikaatiota.

Aluksi fyysisten ja kuvallisten representaatioiden ja myöhemmin abstraktin kalkyylin avulla toteutettu kirjanpito on vakauttanut vakiintuvien yhteisöjen aineelliskommunikatiivisia suhteita. Tunnettua on se, että kirjoitustaidolle loi perustan varhainen palatsikirjanpito Kaksoisvirtain maassa ja Egyptissä sekä yhtä lailla kauempana Aasian itäosissa ja Väli- ja Etelä-Amerikassa.

Leroi-Gourhan korosti sosiaalisesti omaksuttujen yhteisten rytmien merkitystä inhimillisten yhteisöjen vakiintumiselle. Tällaista ajatuslinjaa ovat kehittäneet lukuisat antropologit. Yhteisesti omaksuttujen rytmien puhdaspiirteisintä ilmentymää ovat tanssi ja musiikki. Musiikki on inhimillisenä kulttuurisena muotona ikivanha. On hyvin uskottavaa, että tanssilla ja musiikilla on ollut erityinen merkitys varhaisten ihmisyhteisöjen sosiaalisten sidosten ylläpitäjänä. ${ }^{12}$ Musiikki on yhtä lailla hyvä esimerkki kulttuurisesta toiminta-alasta, jonka muodot ovat tavattomasti monipuolistuneet ja eriytyneet modernin yhteiskunnan uudenlaisten taloudellisten ja teknisten edellytysten myötä. Musiikkikulttuurin eri muotoja ovat muovanneet soittimet, akustiset tilat, yleisöt ja esitystilanteet sekä nuottikirjoituksen ja soittamisen konventiot.

Leroi-Gouhanin teos on joidenkin ihmistymisen evoluutiohistoriaa koskevien yksityiskohtien osalta selvästi vanhentunut. Perusoivallukset ovat kuitenkin päteviä. Leroi-Gourhan korosti, että kyky johdonmukaiseen ajatteluun kasvoi esiin aineel- 
lisen elämän luomasta perustasta. Monet antiikin historioitsijat ovat kehittäneet samanlaista tulkintaa rationaalisen ajattelun varhaisvaiheista kytkien ne klassisen Kreikan kaupunkivaltioiden hallinnon ja fyysisen suunnittelun muutoksiin. Varhaisin tunnettu kreikkalainen kaupunkisuunnittelija oli Hippodamos miletolainen, jonka tiedetään laatineen Pireuksen suunnitelman 400-luvulla e.a.a. Aristoteles mainitsi Hippodamoksen esittäneen kaavailuja myös kaupunkivaltioiden hallinnosta ja lainsäädännöstä. Jean-Pierre Vernant totesi, että Hippodamos oli "poliittinen teoreetikko". ${ }^{13}$

\section{5.}

Ajattelu on "polkuriippuvaista". Uusi rakentuu vanhasta. Ajattelun piiri laajenee tutusta tuntemattomaan. Siksi se, mitä ajattelu voi saada selville uusista ilmiöistä, on väistämättä sidoksissa siihen, mitä se käsitti piiriinsä hetki sitten. Matemaatikko Georg Pólya totesi hienossa kirjassaan Mathematics and Plausible Reasoning, että uuden tiedon tavoittelu lähtee liikkeelle arvauksista ja sisältää aina mahdollisuuden erehtyä. Pólya käytti arvaamisen taidosta nimitystä plausible reasoning ("uskottava päättely"). ${ }^{14}$

Yksilökohtaisesti polkuriippuvuutta tuottaa oppimisen historiallisuus, mutta myös ja vieläpä edellistä painokkaammin tiettyjen ajattelutapojen tai ajattelun kaavojen iskostuminen yksilön toimintatapoihin. Ajattelun polkuriippuvuus merkitsee, että ajattelun kehitystä ja erilaisten ajattelutapojen yhtäläisyyksiä ja eroja ei voi johtaa mistään yhtenäisistä säännöistä.

On tosin perusteita olettaa, että kognition yleisiin ehtoihin vaikuttaa eräänlaisia "pienimmän rasituksen" kaltaisia periaatteita, joita voi ilmetä ainakin kahdella tasolla. Aivojen fysiologiassa tällainen periaate voi syntyä siitä, että keskushermoston sähkövärähtelyiden on synkronoiduttava samoihin rytmeihin. Synkronoituminen toteutuu normaalisti ilman, että ajatteleva organismi on asiasta mitenkään perillä. Kognitiiviset kyvyt ovat perustaltaan luultavasti "privatiivisia" samassa mielessä kuin ihmisorganismin fysiologinen terveys: vasta sairaus tuo terveyden ilmi; vasta mielen hajoaminen tuo mielen eheyden ilmi. ${ }^{15}$

Toisen ryhmän pienimmän rasituksen periaatteita voi oletettavasti kytkeä siihen, että ajattelua määrittävät organismin suhteet ulkoiseen maailmaan. Ajattelu on yksi elävien organismien kognitiivisista kyvyistä joskin monin tavoin erilainen kuin muut eliökunnan piirissä ilmenevät kognitiiviset kyvyt. Rodolfo Llinás on korostanut, että organismien on pakko yksinkertaistaa suhteitaan ympäröivään maailmaan, jotta ne kykenisivät reagoimaan johdonmukaisesti vastaan tulevien ärsykkeiden ja aistimusten vilinään. Olennaista on tunnistaa ympäristön merkitykselliset piirteet, olivatpa merkitykset positiivisia tai negatiivisia. Gärdenforsin termejä käyttäen: monet muutkin organismit kuin ihminen ovat kykeneviä yhdistämään esikäsitteellisen kognition aineksia ilmiöitä luokittelevaksi ja niiden samankaltaisuuksia ryhmitteleväksi käsitteelliseksi kognitioksi. ${ }^{16}$

On hyvinkin uskottavaa, että jonkinlainen "pienimmän rasituksen" periaatteen tapainen sääntö pätee ajatusten ja ideoiden muutoksiin. Mitä muuta logiikan ja matematiikan laskutoimitukset ovat kuin pyrkimystä päätyä mahdollisimman vahvoihin ja yleisiin päätelmiin mahdollisimman vähin aineksin? Sääntöjen yleispätevyyttä rajoittavat niiden syntaksille asettuvat vaatimukset mutta myös kohdealueen luonne. Aritmeettiset laskutoimitukset ovat päteviä maailmaan nähden mikäli matemaattiset oliot ovat analogisia niille olioille, joihin laskutoimitukset viittaavat. Yhteenlasku 
1+1=2 pätee, kun se kohdistuu keskenään samankaltaisiin olioihin, jotka eivät ole vuorovaikutuksessa keskenään. Yhtä lailla $1+1=1$ on oikea tulos esimerkiksi kun lasketaan yhteen yksi kettu ja yksi kaniini.

Koska muodollisten laskutoimitusten eli kalkyylin pätevyysalue on rajallinen, olettaisin, että ajattelun "yksinkertaistamisen" periaate ei pelkisty laskennallisiin operaatioihin. Kalkyylin lisäksi yksinkertaistamista voisi edustaa sellainen erottelukyky, joka jakaa kokemusperäisen maailman käsitteellisesti osiin siten, että ajattelu voi sen avulla täsmentää näkemystä kohteestaan. Dualismit täyttävät tämän funktion. Varhaisten maailmantulkintojen dualistisiin jäsennyksiin viittasin jo edellä. Modernin elämän tulkinnallisiin dualismeihin viittaa esimerkiksi Georg Simmel; tieteellisen selittämisen perustana ovat dualismeja muistuttavat vastakohta-avaruudet; ja niin edelleen. ${ }^{17}$

Käytin aiemmin hämärältä vaikuttavaa ilmaisua "ajattelun maailmallinen asema". Sen perustana on funktionaalisuus, joka on määrittänyt elävien organismien kykyjen ja elintapojen suhteita ympäröivään aineelliseen maailmaan. Organismit ovat riippuvaisia itselleen ulkoisesta maailmasta, jonka tapahtumakulkuja ne eivät voi hallita. Niiden on oltava perillä asemastaan koko ajan muuttuvassa omassa maailmassaan sekä kyettävä reagoimaan oikeilla tavoilla uusiin tapahtumiin. Termillä 'funktio' on huono kaiku analyyttisen filosofian piirissä. Se johtuu väärinkäsityksestä, jonka perustana on uskomus, että kausaalisuhteet ovat yksikäsitteisiä ja lineaarisia. Uskomuksen mukaisesti on kuviteltu, että funktiot ovat välttämättä teleologisia. Ongelma häviää, kun omaksutaan näkemys kehämäisestä, iteratiivisesti toteutuvasta kausaalisuudesta. Kehämäinen kausaalisuus voi tuottaa ilmiöitä, jotka ovat tilannekohtaisesti funktionaalisia ja jotka ovat seurausta niitä edeltäneistä tapahtumakuluista.

Ajatus, että inhimilliset kognitiiviset kyvyt voivat olla funktionaalisia ei suinkaan merkitse, että kognitiiviset kyvyt olisivat kaikkialla samankaltaisia ja että niiden kehitys voitaisiin kuvata yhtenäisten evolutiivisten lainmukaisuuksien perusteella. Alfred Gell korosti, että inhimillisten kulttuurien suhteet ympäröivään aineelliseen maailmaan ja näistä suhteista seuraavat kognitiiviset tarpeet ovat jäsentyneet hyvin moninaisiksi maapallon suuresti vaihtelevissa luonnonoloissa. Se, kuinka yhdenmukaisia ihmisten kognitiiviset kyvyt ovat, on empiirinen kysymys. ${ }^{18}$

On ymmärrettävää, että kielen vanhimmat osat liittyvät perustaviin elinkeinoihin ja niitä ehdollistaviin seikkoihin, kuten ilmastoon, välittömiin luonnonoloihin sekä kehon osiin ja elintoimintoihin. Luonnolliset kielet ovat ilmaisukeinoiltaan kerrostuneita sen seurauksena, että uusia ilmaisutapoja on kehittynyt vanhoista aineksista alun perin ehkä kielen käyttäjien innovatiivisina päähänpistoina. Eri kielet käsittävät erilaisia ilmaisukeinoja samantapaisille asioille, vaikka ne olisivat läheistä sukua toisilleen, kuten latinasta polveutuvat romaaniset kielet. Alfred Gell kuvasi kielen diskursiivisten mahdollisuuksien avartumista termillä "pragmaattis-funktionaaliset tarpeet". Ne eivät välttämättä ole johtaneet yhdenmukaistumiseen, koska tarpeet ovat hyvin eriytyneitä kommunikatiivisten ympäristöjen vaihtelun mukaan. ${ }^{19}$

\section{6.}

Tieteellinen ajattelu on "polkuriippuvaista". Tällainen väite on helppo perustella ainakin kahdesta eri näkökulmasta. Yhtälätä tieteellistä ajattelua jäsentävät vakiintuneet käsitteelliset kehykset ja teoreettiset rakenteet, jotka jokainen tutkija löytää edestään jo olemassa olevina. Toisaalta tieteellisen ajattelun periaatteita hallitsee 
ilmaisun taloudellisuuden vaatimus. Tieteellinen selitys ei voi olla kuin borgesilainen kartta, jonka mittakaava esittämäänsä maisemaan nähden on 1:1. Päinvastoin, tieteellinen selittäminen pyrkii mahdollisimman laaja-alaisiin yleistyksiin.

Palaan George Pólyan ajatuksiin uskottavasta päättelystä: taitoon esittää hyviä arvauksia, kun uutta ilmiötä koetetaan tehdä ymmärrettäväksi liittämällä se vanhan tietämyksen piiriin. Arvauksiin tähtäävän uskottavan päättelyn vastinpari on 'demonstratiivinen päättely', joka perustuu luotettaviksi hyväksyttyihin premisseihin ja noudattaa oikeita päättelysääntöjä. Matematiikkaa pidetään yleensä demonstratiivisen päättelyn valtakuntana. Pólyan radikalismi tulee ilmi siinä, että hän oli matemaatikko ja käytti uskottavan päättelyn esimerkkialana nimenomaan matematiikkaa.

Pólya esitti uskottavan päättelyn tärkeimmiksi muodoiksi induktion ja analogian. Molemmat menetelmät tähtäävät nimenomaan siihen, että uudentyyppinen ilmiö tulee hedelmällisellä tavalla rinnastetuksi vanhojen, jo tunnettujen ilmiöiden kanssa. Pólya oli hyvin perillä induktion oikeutusta vastaan esitetystä filosofisesta kritiikistä mutta sivuutti sen toteamalla, että matematiikan historia "avaa mahdollisuuden tutkia induktiota induktivisesti" ${ }^{20}$

Hedelmällisiä arvauksia tuottaviin menetelmiin voidaan induktion ja analogian lisäksi sisällyttää 'abduktio', Charles Peircen tunnistama päättelyn tapa. Abduktion lähtökohtana on jokin aiemmasta kokemusmaailmasta poikkeava ilmiö, joka luonteensa vuoksi tuntuu vaativan selitystä. Uusi ilmiö on ikään kuin "indeksaalinen" merkki, josta ei tiedetä, minkä merkki se on. Alfred Gell loi abduktiota käyttäen antropologisen teorian taideteosten ja yleisemmin artefaktien kulttuurisesta merkityksestä. Gell loi teoriansa käyttäen semioottista terminologiaa mutta korosti, että abduktio kuuluu pikemmin logiikan kuin semiotiikan piiriin. ${ }^{21}$

Kaikki menetelmät kehittää perusteltuja arvauksia, kuten induktio, analogia ja abduktio, edellyttävät ennakkotietoja niistä ilmiöistä, joita päättely koskee. Siksi ne vahvistavat tieteellisen ajattelun polkuriippuvuutta.

Tieteellisen ajattelun polkuriippuvuuden seurauksena ajattelu urautuu. Opituista ajattelutavoista on vaikea oppia pois siksi, että "unohtaminen" ei voi olla täydellistä. Ajattelu ei voi "alkaa uudelleen alusta". Yksi tämän hankaluuden ilmentymistä on, että uudella tavalla ajattelua tulee helposti hallitsemaan poleeminen suhde vanhalla tavalla ajatteluun. Johonkin rajaan asti tämä on välttämätöntä. Positivistisesta perinteestä irtaantuminen esimerkiksi edellyttää, että positivismin heikkoudet tuodaan ilmi. Seuraava askel, "post-positivistisen" tutkimuksellisen ajattelun esittely, jää kuitenkin harmillisen usein puolitiehen. Omassa ajattelu- ja tutkimustyössäni olen pannut tämän merkille poliittisten prosessien käytäntöihin kohdistuvaa politiikan tutkimusta eli politiikka-analyysia esittelevissä teoksissa, mutta esimerkkejä on tarjolla runsaasti.

\section{7.}

Mielleyhtymät ja rinnastukset ovat ajattelun dynaamisuuden ilmentymiä. Niiden ydin on siirtää käsitteen merkitys alalta toiselle. Kielikuvat eli 'troopit', kuten metafora ja metonymia, toimivat kielen käytännöllisessä hallinnassa samalla tavoin. Mielleyhtymiin perustuvan ajattelun perusmalleja pään ulkopuolella ovat dekoratiivinen taide sekä musiikki. Niiden aineksia ovat toistuvuus ja muutos, rytmit, harmonia ja dissonanssi, ja niin edelleen.

"Intuitio" on nimitys nopeille ja yllättäville mielleyhtymille, jotka muodostuvat 
muistissa olevien kerrostumien uudenlaisina yhdistelminä. Intuitio kehittyy kokemuksen myötä. Tietyntyyppisten ajattelun sääntöjen hyvä, rutiininomainen ja lihasmotoriikkaan tukeutuva hallinta tekee mahdolliseksi poikkeuksellisen intuition, esimerkiksi matematiikassa tai musiikissa. Käsitteellisen ajattelun intuitio ilmenee kykynä oivaltaa tai luoda hedelmällisiä yhteyksiä erilaisten käsitteistöjen välillä.

Hedelmällisten assosiaatioiden ainekset kypsyvät ajan myötä. Mielleyhtymät tosin voivat syntyä ennakoimattomasti, kuten lukuisat esimerkit tieteellisestä kekseliäisyydestä osoittavat, mutta se, muodostuuko tietty rajoja ylittävä assosiaatio hedelmälliseksi vai ei, on perinteen rikkauden ja syvyyden ehdollistamaa.

Yleisnimet, jotka nivovat ulkonaisesti erilaisia ilmiöitä yhteen, ovat ylimalkaan arvoituksellisia. Kolibri, varis ja strutsi ovat kaikki 'lintuja'. Luokitukset ovat olleet tieteellisen yleistämisen olennainen ja usein hyvin innovatiivinen muoto. Linnén luoma eliökunnan luokittelu ja Mendelejevin luoma alkuaineiden jaksollinen järjestelmä ovat tunnettuja esimerkkejä. Luokitusten merkitys on siinä, miten tiettyihin luokkiin kuuluvien objektien samankaltaisuus perustellaan.

Merkityksellisen samankaltaisuuden tunnistaminen on pannut alulle merkittäviä tieteellisen ajattelun murroksia. Newton oivalsi, että omenan putoaminen puusta on oikeastaan sama tapahtumakulku kuin planeetan liike aurinkoa ympäröivällä radallaan; modernin termodynamiikan perustan laskijat oivalsivat, että vesihöyryn tiivistyminen vedeksi ja veturin liike ovat oikeastaan samoja ilmiöitä; ja niin edelleen.

Liiallinen erikoistuminen mainitaan usein piirteeksi, joka kuihduttaa modernin yhteiskunnan kulttuurista ilmastoa. On hyvin vaikeaa arvioida, onko tilanne tässä suhteessa nykyisin huonompi kuin varhaisempina aikoina. Ilmeistä kuitenkin on, että nykymaailmassa erilaiset asiat liittyvät toisiinsa useammanlaisilla tavoilla kuin aiemmin. Kompleksin yhteiskunnan moniulotteiset ongelmat vaativat moniulotteista ajattelua. Käytännöllinen työ, kielellinen työ ja kognitiivinen työ muodostavat kolmiyhteyden, jota tulee vaalia. Yhteydet jäsentyvät esimerkiksi pohdittaessa ja selvennettäessä tieteellisen ja arkisen ajattelun ja kokemuksen yhteyksiä ja eroja. Ne eivät ole luonnostaan ilmeneviä, joten ne on jatkuvasti arvioitava uudelleen.

Käytännöllisen, kielellisen ja kognitiivisen työn yhteyksistä ovat saaneet alkunsa kulttuurin perustana olevat moninaiset taidot, jotka ovat irtaantuneet alkuperäisestä yhteydestään ja itsenäistyneet ihmisten arkisen elämän estetiikan sekä myös eriytyvän taiteellisen ilmaisun erilaisiksi muodoiksi. Kielellisen ilmaisun vapaa leikki alkoi siitä, kun kirjoitustaito arkipäiväistyi kreikkalaisessa poliksessa.

\section{8.}

Ajattelua suuntaavat eteenpäin dynaamiset projektiot. Ajattelun kohde voi "herätä eloon" ja luoda ytimen kuvitteelliselle, tulevaisuuteen sijoittuvalle merkitysten kimpulle. Afred Gellin antropologinen taideteoria käsittää ajatuksen, että taideteokset ja huomiota herättävät artefaktit, joita niin sanottujen primitiivisten kansojen taideteokset yleensä ovat, omaavat 'sosiaalista toimijuutta' (social agency). Sen mekanismi on hiukan yksinkertaistaen ilmaistuna abduktio: merkitykselliset artefaktit ovat eräänlaisia "merkkejä", joille niiden katsojat ("potilaat", patients, on Gellin käyttämä tavallisesta poikkeava termi) postuloivat merkityksiä. Merkitykset voivat kytkeytyä ajallisia tapahtumakulkuja muistuttaviksi ketjuiksi. Ajallinen ulottuvuus tosin syntyy jo siitä, että monimutkaisia ja merkityksellisiä artefakteja ei voi havainnoida muuten kuin aikaa vaativina ja aikaan sidottuina tapahtumakulkuina. Erityisesti toistoon 
perustuvat kuviot, joita helposti leimataan "pelkäksi dekoraatioksi", heräävät eloon sen seurauksena, että niiden katsominen on ajallinen prosessi. ${ }^{22}$

Clive Gamble on käyttänyt ilmausta 'symbolinen voima' kuvaamaan sitä, miten käytännöllisesti merkitykselliset artefaktit ovat ihmistymisen historian kuluessa jäsentäneet yhteisöjen toimia, määrittäneet toimien merkityksiä sekä luoneet niille jatkuvuutta. Gamblen tulkinnan mukaan artefaktit saavat symbolisen voimansa kehollisista kokemuksista ja aistimuksista. Ihminen tulee toimivana, aineellisena oliona liitetyksi muun aineellisen maailman tapahtumakulkuihin, joissa hän on itse osallisena ja joista hän on riippuvainen. ${ }^{23}$

Inhimillinen kieli on symboleihin perustuva kokonaisuus, mutta inhimillisiä kulttuureja jäsentävä symbolisuus ei pelkisty kieleen. Merkityksiä jäsentävät semanttiset tilat muodostuvat aineellisista suhteista inhimillisten elämänkäytäntöjen ja fysikaalisbiologisen ympäristön välillä. Dekoratiiviset ilmaisumuodot ovat tarjonneet yhden perustan semanttisten, merkityksiä kantavien tilojen muodostamiselle. Dekoraatio on grafismia. Kuvioiden avulla inhimillisten kulttuurien maailmaa ja kulttuurien suhteita fyysiseen maailmaan voidaan "siirtää" ulkoisesti läsnäoleviksi opastuksiksi ja varotuksiksi. Erityisen kiinnostavia esimerkkejä tarjoavat labyrinttikuviot, jotka toistuvat mitä moninaisimmissa muodoissa maailman eri kulttuureissa. Labyrintit sijaitsevat menneisyyden ja tulevaisuuden vaihettumisvyöhykkeellä.

\section{9.}

Ajatteluun kohdistuu omanlaatuisensa kurinpito. Sen olennaisen juonteen ilmaisee Platonin Menon-dialogin jakso, jossa Sokrates perustelee, miksi tieto on arvokkaampi kuin oikea mielipide: "Kun ne (oikeat mielipiteet) siis on näin sidottu, ne muuttuvat ensin tiedoksi ja sitten pysyviksi. Sillä tavoin tieto on arvokkaampaa kuin oikea mielipide ja tiedon erottaa oikeasta mielipiteestä juuri se, että tieto on sidottu." ${ }^{24}$

Platonin katkelma voidaan tulkita eri tavoin. Yhtäältä se perustelee vallitsevien näkemysten konformistisen ylivallan, jolla on tukenaan tiedon yhtenäisyyden idea. Mutta arkkitehtuurin historioitsija Indra Kagis McEwen pitää Sokrateen ilmaisemaa ajatusta muistumana ajalta ennen kirjoitetun kielen ja filosofian syntyä. Tiedon sidonnaisuus ei McEwenin tulkinnan mukaan kohdistukaan opilliseen kaanoniin vaan maailmoja luoviin konkreettisiin käytäntöihin kuten arkkitehtuuriin ja käsityöläistaitoihin, jotka ovat muodostaneet abstraktin tietämyksen perustan ja kasvualustan. Dialogin ihanne ei siis ehkä olekaan rationaalisen ajattelun puhdasoppisuus vaan käytännöistä kasvavan tietämyksen dynaaminen potentiaali. ${ }^{25}$

Historiallinen kokemus tietenkin on osoittanut moninkertaisesti, että oikeaoppisuus on ollut ajattelulle tuhoisa kahle. Platonin tietoteoriaa ei kuitenkaan ole tarvittu sen perusteluksi. Poliittinen ja uskonnollinen sorto on ollut itseriittoista. Intellektuaalisen sorron teemaa ei ole kuitenkaan mahdollista käsitellä tässä yhteydessä.

\section{0 .}

Tieteelliseen ajatteluun kohdistuu omanlaatuisensa kurinpito, jota kannattelevat tieteellisen yhteisön piirissä omaksutut konventiot. Konventioita koskevat kiistat voivat redusoitua vallankäytön ristiriidoiksi, joita Pierre Bourdieu analysoi kamppailuna akateemisen kentän hegemoniasta. Ilmiöllä on kuitenkin myös tutkimuksellisiin käytäntöihin ja tieteellisen ajattelun dynamiikkaan liittyviä ulottuvuuksia. Omilla 
tutkimusaloillani on esimerkiksi tietyistä ideoista muodostunut eräänlaisia "atraktoreita", joita kohti tutkimuksellinen ajattelu suuntautuu empiriasta riippumatta kuin itsestään, kuin vastustamattomien voimien pakottamana. "Panchreston" on ajattelua sitoviin atraktoreihin viittaava anglo-amerikkalainen termi. ${ }^{26}$

Myös metodologiset konventiot voivat vaikuttaa kurinpidon tavoin. Matematiikalla on ollut kaikessa tieteellisessä päättelyssä olennainen merkitys uuden ajan alusta lähtien. Kuten edellä totesin, matematiikan soveltaminen edellyttää, että tutkimuskohteeksi valitut ilmiöt kyetään esittämään matemaattisten objektien kaltaisiksi. Tutkimuskohteiden ja matemaattisten objektien välinen suhde on itse asiassa analogia. Henri Poincaré tiivisti analogian seuraavaan toteamukseen: ${ }^{27}$

"Voitaisiin kysyä, miksi yleistys ottaa fysikaalisissa tieteissä niin kärkkäästi matemaattisen muodon [...] tämä johtuu siitä, että havaittavissa oleva ilmiö syntyy suuresta määrästä toisiinsa vaikuttavia alkeisilmiöitä, jotka ovat kaikki keskenään samanlaisia; ja tällä tavoin differentiaaliyhtälöt otetaan aivan luonnollisesti käyttöön.”

Genealogia on menetelmä selvittää rajatumpien ajatustapojen ja tiedon muotojen taustoja. Tutkimuksellisten käytäntöjen näkökulmasta genealogisen tutkimuksen erityisen kiinnostavia kysymyksiä ovat: Millaisista aineksista aiemmat menestykselliset ajatusmuodot ovat alunperin koostuneet? Millaisilla tiedollisilla, käytännöllisillä ja sosiaalisilla edellytyksillä ajatusmuodot ovat aikanaan vakiintuneet?

Pidin 2000-luvun jälkipuoliskolla usean vuoden ajan ympäristöpolitiikan syventäviin opintoihin sisältynyttä kurssia "dynaaminen ajattelu". Perusteluni kurssille oli se, että ajattelun periaatteita ja menetelmiä on mahdollista oppia ja harjoitella. 'Menetelmä' on moniulotteinen käsite. Menetelmällisen ajattelun ulottuvuuksia voi eriyttää termeillä 'metodi', 'metodologia' ja 'heuristiikka'. Kurssin sisältö kohdistui pääasiassa tutkimuksellisen ajattelun heuristiikkaan: näkemykseen siitä, millaisin edellytyksin tietyntyyppisten ongelmien käsittäminen ja selittäminen on ylimalkaan mahdollista.

Ajattelun "lait" tai "säännöt" eivät kuulu tähän jäsennykseen. Vain pieni osa ajattelusta perustuu systemaattisiin sääntöihin. Ajattelun heuristiikka käsittää merkittävän kokemusperäisen ulottuvuuden. Amos Tverskyn ja Daniel Kahnemanin tunnetuksi tekemä idea, että epävarmuuden arviointiin sovellettuun heuristiikkaan sisältyy harhaa (bias) on tärkeä mutta tarpeettoman kapea-alainen tulkinta heuristiikasta. Laajemmin ymmärrettyä heuristiikkaa selventää tieteellisen päättelyn genealogia. Genealogian tavoite ei ole "suhteellistaa" tieteellisiä käsityksiä jonkinlaisen relativismin mielessä vaan suhteuttaa: tunnistaa sellaisia asioita ja ilmiöitä, jotka ovat tehneet tietyntyyppiset uudet ajattelutavat mahdollisiksi. Genealogia tuo siten myös ilmi ajattelutapojen käytännöllisiä ja käsitteellisiä ehtoja.

Ajattelun dynaamisuutta koskevaan jäsennykseen sisältyy luvuton määrä teemoja, joihin liittyy filosofisia ja aatehistoriallisia kiistoja. Niihin on kuitenkin käytännössä mahdotonta kiinnittää erityistä huomiota. Mikäli filosofiset kiistakysymykset nousisivat etusijalle, tutkimukselliset käytännöt jäisivät taustalle. Ehkä tällaista tulkintaa heuristiikasta voidaan moittia ohuen pragmaattiseksi. En toki kiistä sitä, että hienopiirteiset filosofiset ongelmat ovat kiinnostavia ja että ne nostavat esiin myös tutkimuksellisten ongelmien ratkaisemiselle merkityksellisiä seikkoja. Uskon kuitenkin, että tervejärkinen pragmaattisuus on ongelmien ratkaisemiseen pyrkivälle tutkimukselle välttämätöntä. 
Ongelmia ratkova ajattelu suuntautuu liikkuvaan kohteeseen. Dynaaminen ajattelu voi tavoittaa liikkuvan kohteen. Kohteen liikkuminen tarkoittaa erityisesti ympäristöpolitiikan alalla sitä, että ajattelun kohde sijaitsee tulevaisuudessa.

Tulevaisuuden problematisoitumista ilmentää esimerkiksi ilmastonmuutos. Ilmaston lämpenemisen mekanismit ymmärretään nykyisin jokseenkin hyvin, mutta ilmiön luonteesta johtuu, että lämpenemisestä on mahdotonta esittää kovin täsmällisiä ennusteita ja että sen seurauksia on erityisen vaikea ennakoida. Vielä vaikeampia ongelmia aiheutuu siitä, että moderni yhteiskunta on sidoksissa taloudelliseen kasvuun. Parin kolmen vuosisadan ajan jatkunut taloudellinen kasvu on nykyisessä muodossaan tiensä päässä. Kasvusta luopumisen pakko on "degrowth" nimikkeellä noussut keskusteluun, mutta on vaikea kuvitella, miten kasvusta irtaantuminen voi tosiasiallisesti tapahtua. Mikä voi pitää yhteiskunnat koossa, kun hyvinvoinnin kasvun lupaukselta murenee perusta?

Tulevaisuus on olemassa ennen todellistumistaan ennusteina, ajatuksina, kaavailuina ja suunnitelmina. Optimistinen olettamus on, että kun kerran tulevaisuuden kuvat ovat ajatusprosessien tuotetta, niitä voidaan myös ajatellen, keskustellen ja uudenlaisia symbolisia, tulevaisuuteen suuntautuvia merkityksiä luoden muuttaa. Vastakkaista vaihtoehtoa en uskalla ajatella.

\section{$v i \mathrm{i} t \mathrm{t}$ e $\mathrm{t}$}

1. Cornelius Castoriadis, Philosophy, Politics, Autonomy. Essays in Political Philosophy. Oxford University Press, 1991.

2. Korkealaatuisen ravinnon merkitystä koskevan "expensive tissue" hypoteesin kehittivät antropologit Leslie Aiello ja Peter Wheeler: "The Expensive-Tissue Hypothesis. The Brain and the Digestive System in Human and Primate Evolution", Current Anthropology 36: 199-221, 1995. Daniel Smail, On Deep History and the Brain, University of California Press, 2008, esittää hypoteesista historioitsijana hyvin positiivisen arvion.

3. Marcel Mauss, A General Theory of Magic, Routledge, 2001.

4. Peter Gärdenfors, Conceptual Spaces. The Geometry of Thought. The MIT Press, 2000.

5. Edellisestä ks. Thorkild Jacobsen, The Treasures of Darkness. A History of Mesopotamian Religion, Yale University Press, 1976; jälkimmäisestä klassinen esitys on G.E.R. Lloyd, Polarity and Analogy. Two Types of Argumentation in Early Greek Thought, Cambridge University Press, 1966.

6. Keskushermoston rytmeistä erityisen valaisevia yleisesityksiä ovat Rodolfo Llinás, $i$ of the Vortex. From Neurons to Self, The MIT Press, 2001, sekä György Buzsáki, Rhythms of the Brain, Oxford University Press, 2006.

7. Joseph Schumpeter, History of Economic Analysis, Routledge, 1954, 79; George Pólya, Mathematical Methods in Science, The Mathematial Association of America, 1963, 105.

8. Alfred Gell, Art and Agency. An Anthropological Theory, Oxford University Press, 1998, 75; Marcel Detienne, The Masters of Truth in Archaic Greece, Zone Books, 1999, 27.

9. Wittgenstein, Varmuudesta, WSOY, 1969, aforismi 105.

10. André Leroi-Gourhan, Gesture and Speech, The MIT Press, 1993. Teos käsittää analyysin paleoliittisen taiteen symbolikielestä, josta Leroi-Gourhan julkaisi myös erillisiä tutkielmia, kuten monumentaalisen Treasures of Prehistoric Art, Abrams, 1967.

11. Clive Gamble, The Palaeolithic Societies of Europe, Cambridge University Press, 1999.

12. William Benzon, Beethoven's Anvil. Music in Mind and Culture, Basic Books, 2001.

13. Jean-Pierre Vernant, The Origins of Greek Thought, Cornell University Press, 1982; E.J. Owens, The City in the Greek and Roman Worlds, Routledge, 1991.

14. George Pólya, Mathematics and Plausible Reasoning. Volume I, Induction and Analogy in Mathematics, Princeton University Press, 1954.

15. "Privatiivinen" on G.H von Wrightin terveyteen soveltama määre; Hyvän muunnelmat, 
Otava, 2001, 101-2.

16. Termi "käsitteellinen" saattaa vaikuttaa liian vaateliaalta sovellettuna muihin eläimiin kuin ihmisiin, mutta itse asia ei ole sanallisesta ilmaisusta riippuvainen. Olen kokemukseni perusteella täysin vakuuttunut siitä, että esimerkiksi koira voi tajuta, että sillä on valittavanaan kaksi toisensa poissulkevaa käyttäytymisen vaihtoehtoa ja päätyä harkintansa perusteella valitsemaan niistä toisen.

17. Simmelistä: Arto Noro, Muoto, moderniteetti ja 'kolmas'. Tutkielma Georg Simmelin sosiologiasta, Tutkijaliitto, 1991, 70. Vastakohta-avaruudesta selittämisen perustana: Alan Garfinkel, Forms of Explanation. Rethinking the Questions in Social Theory, Yale University Press, 1981.

18. Alfred Gell, The Anthropology of Time. Cultural Constructions of Temporal Maps and Images. Berg, 1992.

19. Gell, emt. (viite 18), 131.

20. Pólya, emt. (viite 14), lainaus johdannossa (korostus alkutekstissä).

21. Gell, emt. (viite 8); Gell käyttää taideteosten ja artefaktien tulkintaa koskevassa teoriassaan semiotiikan käsitteistöä, mutta vastustaa kielellistä tulkintaa. Abduktion semiotiikasta ks. Umberto Eco, Semiotics and the Philosophy of Language, Macmillan, 1984.

22. Gell, emt. (viite 8); analyysi dekoratiivisten kuvioiden "elävyydestä" s. 73-82.

23. Clive Gamble, Origins and Revolutions. Human Identity in Earliest Prehistory, Cambridge University Press, 2007, 90-92.

24. Platon, Teokset 2, Otava 1978, suom. Marianna Tyni, 98a.

25. Indra Kagis McEwen, Socrates'Ancestor. An Essay on Architectural Beginnings, The MIT Press, 1993.

26. Yrjö Haila, "The conceptual genealogy of fragmentation research: from island biogeography to landscape ecology" ,Ecological Applications 12: 321-334, 2002; David Lindenmayer \& Joern Fischer, "Tackling the habitat fragmentation panchreston", Trends in Ecology and Evolution 22: 127-132, 2007.

27. Henri Poincaré, Science and Hypotesis, Dover, 1952, 158 (korostus alkutekstissä). 